\title{
THE SARUKUBO CONGLOMERATE
}

\author{
KAZUYOSHI OKAMI*
}

(Received June 14, 1972)

\section{Introduction}

The occurrence of orthoquartzite pebbles hitherto regarded as of Precambrian origin has been recently reported from several localities in Japan, such as the Shimanto terrain (TokUokA, 1967, 1970; The Kishu Shimanto Research Group, 1968), Tanba belt (Research Group of the Tanba Belt, 1971) and the Mino belt (ADAGHI, 1971). The precambrian terrain from which the orthoquartzite pebbles are inferred to have been derived, is postulated by THE Kishu Shimanto Research Group and Adachi to have existed under the oldest dated rocks, the Silurian System, and to have extensive distribution southeastwards (Pacific side) and also northwestwards (Japan sea side) beyond the area of the present Japanese Islands. The radiometric dating of the silimanite gneiss pebbles of the $\mathrm{Ka}$ miaso Conglomerate of the Mino belt indicates the Precambrian age (Shibata et al., 1971), and may support the postulation expressed by THE Krshu Shimanto Research Group (1968) and ADACHI (1971).

The orthoquartzite pebbles newly discovered from the Mesozoic Sarukubo Conglomerate distributed in the Torinoko mountain block of the Yamizo Mountains, Ibaraki Prefecture, Northeast Japan form the subject of the present article. The occurrence of the orthoquartzite pebbles from Northeast Japan may be important for consideration of the geostructural relationship between Southwest and Northeast Japan because the hitherto known orthoquartzite pebbles of Japan have been restricted to Southwest Japan. The pebbles may also serve for the reconstruction of the geotectonic history of the Abukuma Plateau and the Yamizo Mountains.

In this paper the Sarukubo Conglomerate is described and discussed mainly from the view point of sedimentary petrology with special reference to the geotectonic history of the southern Abukuma Plateau.

* Department of Mining and Civil Engineering, Faculty of Technology, Iwate University.

\section{Acknowledgments}

I wish to express my thanks to Professor Kotora Hatar for his critical reading of the manuscript and Dr. Masafumi Murata for his valuable advices, both of the Institute of Geology and Paleontology of the Tohoku University. Thanks are due to Professor Toshiji Oyama and Drs. Toshio SaIto and Haruyuki TAkAhashi of the Department of Greology, Ibaraki University for their kind advices and suggestions. Appreciation is also expressed to Mr. Kentaro Orawa and some students of the Ibaraki University for their kind advices in many different ways.

\section{Outline of the Geology}

The geology of the Yamizo Mountains that include the Yamizo (strict sense), Torinoko and Toriashi (Keisoku of some authors) mountain blocks from north to south have been made by Fujimoto and Hatakeyama (1938), Kawada and Kanomata (1948), KaWAda (1953), Kano (1960), Kanomata (1961), Kasai and Kimura (1971) and Kasal and Oyama (1972).

Those mountain blocks consist mainly of sandstone and shale with intercalated layers of chert and small limestone lenses of Mesozoic and Paleozoic age. According to Kanomatra (1961), the rocks can be classified into the Paleozoic $\mathrm{Ka}$ sama Group and the Mesozoic Yamizo Group. The latter group is divided into the five formations, namely Kunimiyama, Toriashisan, Yamizosan, Torinokosan and Karasuyama formations in descending order superposed with conformity from east to west (Table 1). The Mesozoic age of the Yamizo Group was determined by the radiolaria assemblage from the chert and siliceous shale of various localities and a fossil wood Dadoxylon (Araucarioxylon?) (Kanomata, 1961). Recently, from the Torinokosan Formation Kranaosphinctes matsushimai (YoxoyAmA) (Jurassic Oxfordian age) has been found (Suzuri and Sato, 1972).

The brief descriptions, according to KanOMATA (1961), of each formation of the Yamizo Group 


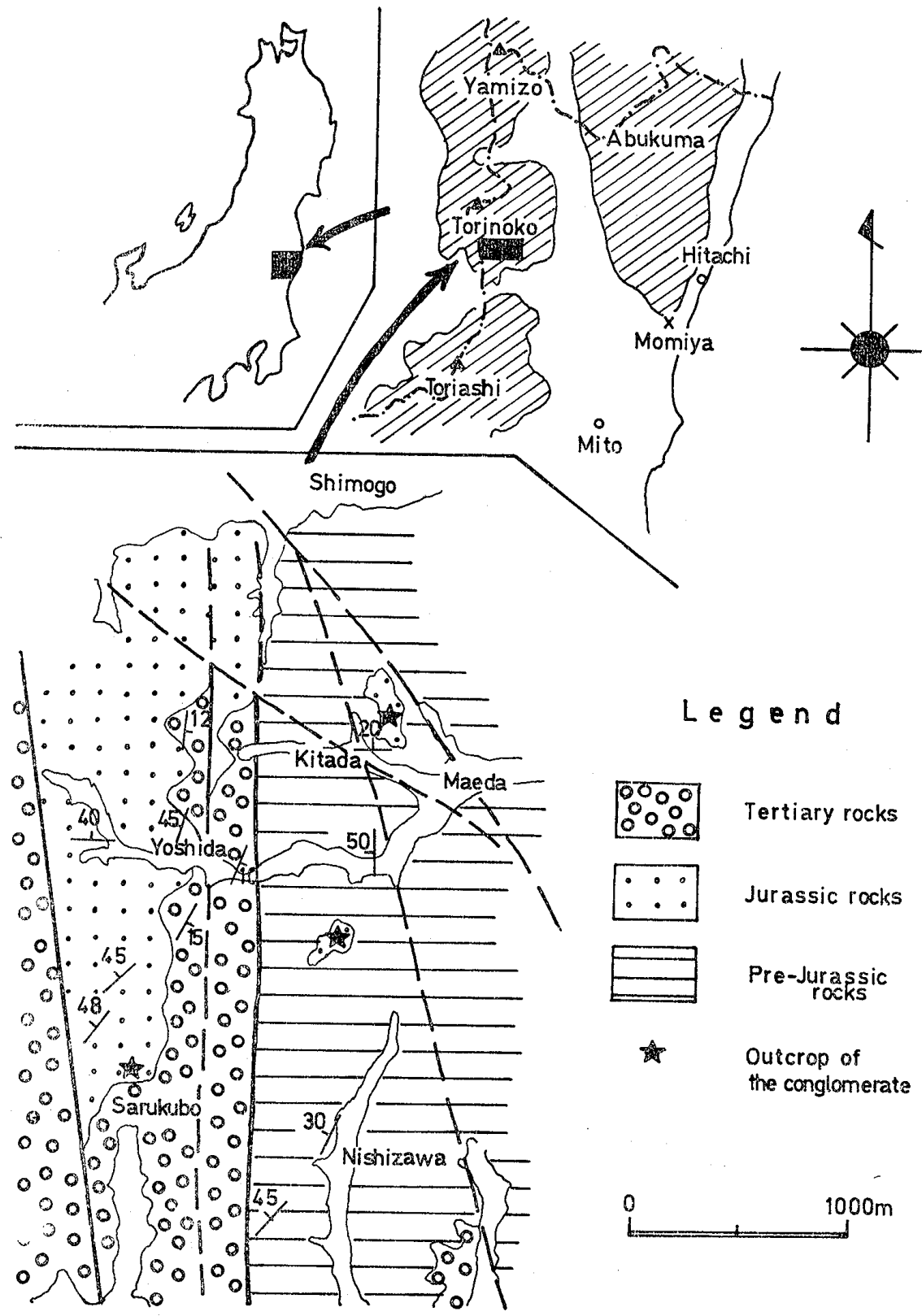

Fig. 1. Geologic map of the Sarukubo area, Ibaraki Prefecture,

Table 1. Stratigraphic unit of the Yamizo Mountains (KANomata, 1961).

\begin{tabular}{l|l}
\hline \multirow{3}{*}{ YAMIZO GROUP } & Karasuyama F. \\
& Torinokosan F. \\
& Yamizosan F. \\
& Toriashisan F. \\
& Kunimiyama F. \\
& Fault \\
\hline
\end{tabular}

KASAMA GROUP

are as follows;

The Kunimiyama Formation with a thickness of about $3000 \mathrm{~m}$, distributed in the Kunimiyama area of Toriashi mountain block, consists of sandstone and shale and their alternation. In the southern part of Toriashi mountain block the Kunimiyama Formation is in contact with the Paleozoic Kasama Group by fault.

The Toriashisan Formation consists of sandstone and shale with three layers of chert that can be traced throughout the whole area of the Yamizo Mountains. The thickness of the formation is estimated to be about $4000 \mathrm{~m}$.

The Yamizosan Formation about $2000 \mathrm{~m}$ in thickness distributed typically in the central part of the Torinoko mountain block is composed of sandstone and shale; the sandstone is dominant.

The Torinokosan Formation is estimated to be about $2000 \mathrm{~m}$ in thickness. It consists of sand- 
stone and shale similar to the subjacent Yamizosan Formation. The distinction between the two formations resides in the fact that shale is dominant in the Torinokosan Formation and sandstone is dominant in the Yamizosan Formation.

The Karasuyama Formation, the uppermost unit of the Yamizo Group, consists of sandstone and shale intercalated with a thin layer of chert and conglomerate (Sarukubo Conglomerate). The thickness of the formation is about $2500 \mathrm{~m}$.

A brief description of the Yamizo Group was given by KANOMATA as mentioned above, but since then, with the progress of study, different opinions have been introduced, particularly concerning the geostructure of the Yamizo Mountains (KAsaI and Kimura, 1971). The current view denies the westward dipping homoclinal sequence of the strata, and expresses the repetition of strata in three times caused by reverse faults trending parallel to the strike of the beds. Because of the repetition of the strata by reverse faults, the nomenclature of the formation becomes complicated. For example in the Toriashi mountain block, Kanomata's Kunimiyama Formation is divided into the Kunimiyama (lower) and Keisokusan (upper) formations, and Toriashisan, Yamizosan and Torinokosan formations of Kanomata (the Karasuyama Formation does not exist in this block) are reclassified into the Kasama (Paleozoic), Kunimiyama and Keisokusan formations (Oyama et al., ms). In the Torinoko and Yamizo mountain blocks, the geostructure and stratigraphy is more complicated than in the Toriashi mountain block. Further discussions are not present here because it is out of the scope of the present article.

The area dealt with in this article is situated at the southern periphery of the Torinoko mountain (Fig. 1). The Yamizo Group of this area has a general strike and $\operatorname{dip}$ of $\mathrm{N} 20^{\circ} \mathrm{W}, 50^{\circ} \mathrm{W}$, and is structurally homoclinal, the strata superposed with conformity from east to west. The typical distribution area of the Sarukubo Conglomerate is situated in a narrow area, along the road leading from Sarukubo to Yoshida in Naka County, Ibaraki Prefecture. The area is cut by two faults each of N-S trend (Fig. 1). The Sarukubo Conglomerate in the southern part of this area is covered by the Tertiary rocks with unconformity. The Sarukubo Conglomerate continues northward to the adjacent area. The rocks in the Sarukubo area have a general strike and dip of $\mathrm{N} 50^{\circ} \mathrm{E}, 45^{\circ} \mathrm{W}$, which is different from the trend in the adjacent area.

\section{Sedimentary Petrology of the Sarukubo Conglomerate}

\section{Sarukubo Conglomerate (General Set- ting)}

The Sarukubo Conglomerate (KAwadA and Kanomata, 1948) is typically developed in the cliff of the road leading from Sarukubo to Yoshida

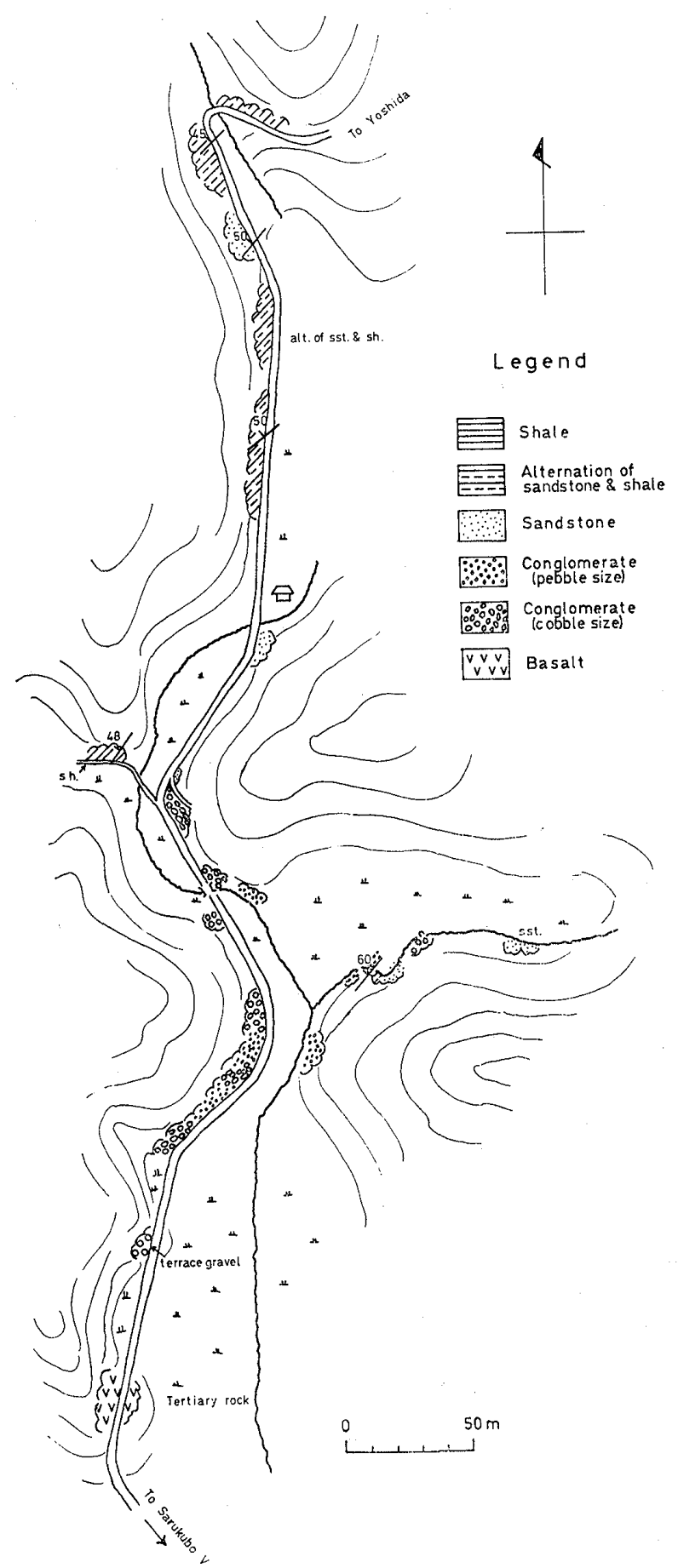

Fig. 2. Route map along the road leading from Sarukubo to Yoshida. 


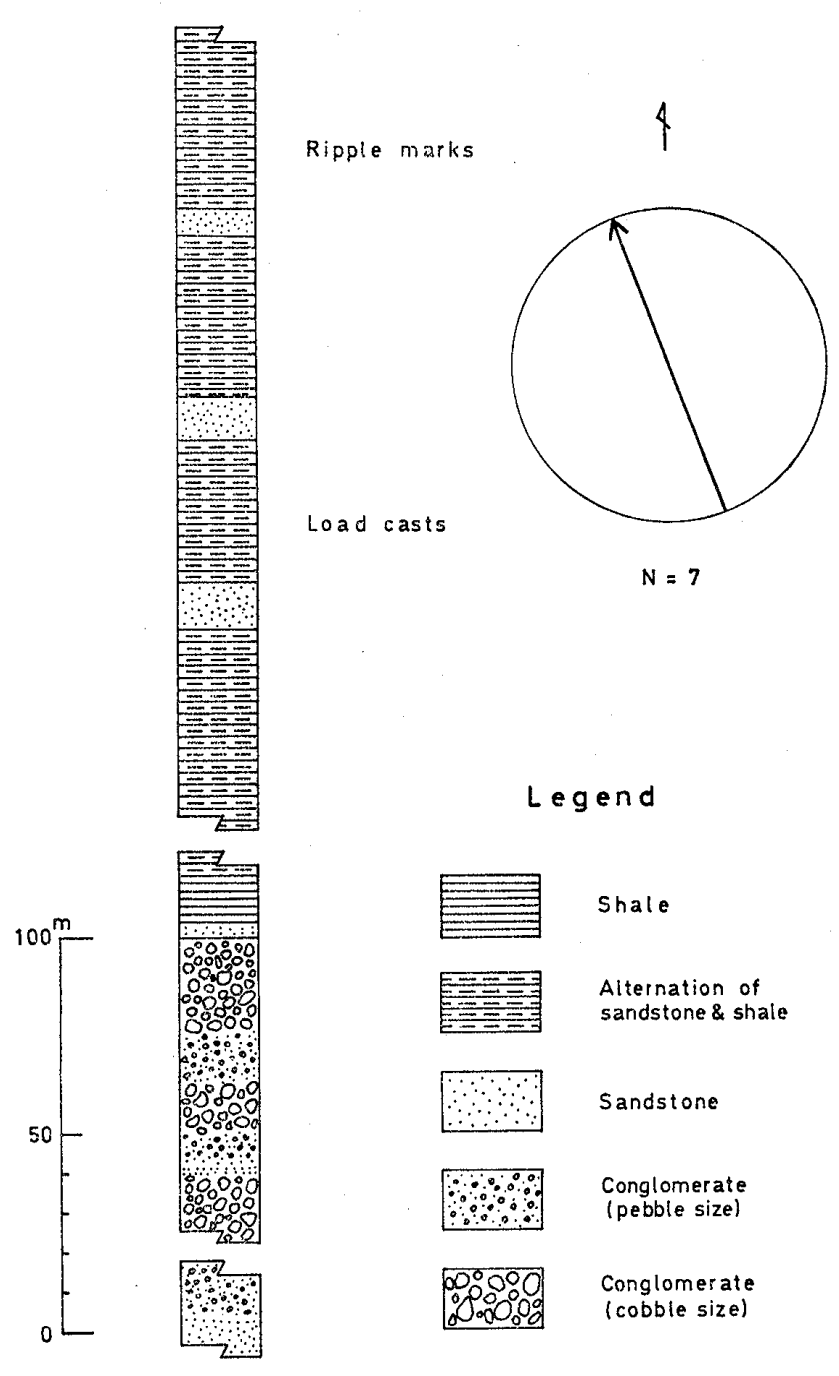

Fig. 3. Columnar section of the Sarukubo area, fand the paleocurrent direction (arrow represents azimuthal arithmatic mean).

in Naka County, Ibaraki Prefecture. Its distribution continues to the summit of the mountain in the adjacent area. The outcrops of the Conglomerate in the Sarukubo and adjacent areas is small as shown in the route map (Fig. 2). The sequence of the Sarukubo Conglomerate observed along the road mentioned above is, from the lower, cobble size conglomerate intercalated with thin sandstone and shale, thin laminated sandy shale, alternation of fine grained sandstone and sandy shale intercalating coarse grained sandstone (3$4 \mathrm{~m})$. The lower part of the Sarukubo Conglomerate is unknown because it is overlain by the Tertiary rock with unconformity. The Sarukubo Conglomerate mentioned above represents the lower conglomerate unit of the above sequence, and has a thickness of about $60 \mathrm{~m}$ (Fig.
3). The Sarukubo Conglomerate consists of three cobble size conglomerate layers, two pebble size conglomerate layers, with thin sandstone and shale layers. The thickest layer of cobble size conglomerate is the uppermost one which has a thickness about $20 \mathrm{~m}$ including a thin sandy shale layer in the middle part. The alternation layers in the upper part of the Sarukubo Conglomerate include the abundant plant fragments.

The Sarukubo Conglomerate was considered to be the basal conglomerate of the Torinokosan Formation by KAWADA (1953), and subsequently, Kanomata (1961) regarded this conglomerate to be an intraformational conglomerate of the Karasuyama Formation. However, recently KASAI and Oyama (1972) suggested that the Sarukubo Conglomerate represents the basal conglomerate of the Keisokusan Formation (same as Karasuyama Formation) as is evident from the sharp difference in the lithofacies of the superjacent and subjacent strata. The writer holds the view that the Sarukubo Conglomerate is the basal conglomerate of the Keisokusan Formation (Kasar and Oxama, 1972), because the lithofacies of the superjacent sandistone changes abruptly to arkosic and the because of the discordant distribution of the Sarukubo Conglomerate to the subjacent strata (Fig. 1). The alteraation layers of the strata superjacent to the conglomerate contain abundant plant leaves and fragments and the internal structure of the alternation layers does not show turbidite facies. The alternation layers are thus considered to represent the mixed depositional environment.

The Sarukubo Conglomerate is composed dominantly of cobble size pebbles and sporadically of boulder size pebbles attaining as much as $40 \mathrm{~cm}$ in maximum diameter (PI. 1). The pebbles are shaped variously from well rounded to angular (Powers, 1952). The matrix consijts of coarse grained sandstone and the conglomerate is loosely packed. The sandy matrix of the conglomerate is very arkosic, consisting of quartz $55 \%$, feldspars $22 \%$, mica (biotite) $0.4 \%$, rock fragments (sandstone, quartz porphyry, aplite, clayey material and so on) $10 \%$ and matrix (under $5 \phi$ ) about $5 \%$ (Table 3 ). The grains are angular and not beyond the subangular grade. The textural parameters of the sandstone constituting the matrix of the conglomerate are of mean size $1.6 \phi$, sorting degree 1.17 , skewness 0.25 (Table 4).

\section{Constituents and Composition of the Sarukubo Conglomerate}

The Sarukubo Conglomerate comprises pebbles of sandstone, slate, chert, limestone, clayey rocks, 
Table 2. Composition of the pebble species of the Sarukubo Conglomerate. $\mathrm{N}$ : total_number_of counted.

\begin{tabular}{|c|c|c|c|c|c|c|}
\hline & \multicolumn{2}{|c|}{ Sarukubo } & \multicolumn{2}{|c|}{ Kitada No. 1} & \multicolumn{2}{|c|}{ Kitada No. 2} \\
\hline $\begin{array}{l}\text { chert } \\
\text { sandstone } \\
\text { slate } \\
\text { orthoquartzite } \\
\text { limestone } \\
\text { vein quartz } \\
\text { granite } \\
\text { porphyrite } \\
\text { porphyry } \\
\text { others }\end{array}$ & $\begin{array}{r}38 \\
11 \\
11 \\
4 \\
1 \\
8 \\
4 \\
2 \\
1 \\
1 \\
15 \\
\mathrm{~N}=95\end{array}$ & $\begin{array}{c}40.0 \% \\
11.5 \\
11.5 \\
4.2 \\
1.0 \\
8.4 \\
4.2 \\
2.1 \\
1.0 \\
15.8 \\
99.7\end{array}$ & $\begin{array}{r}52 \\
24 \\
11 \\
1 \\
1 \\
1 \\
2 \\
-1 \\
\mathrm{~N}=103\end{array}$ & $\begin{array}{c}50.5 \% \\
23.3 \\
10.7 \\
0.9 \\
0.9 \\
0.9 \\
1.8 \\
0 . \overline{9} \\
9.7 \\
99.6\end{array}$ & $\begin{array}{r}35 \\
14 \\
9 \\
5 \\
1 \\
1 \\
1 \\
- \\
-6 \\
\mathrm{~N}=72\end{array}$ & $\begin{array}{c}48.6 \% \\
19.4 \\
12.4 \\
6.9 \\
1.4 \\
1.4 \\
1.4 \\
\overline{-} \\
8.3 \\
99.8\end{array}$ \\
\hline
\end{tabular}

Sarukubo

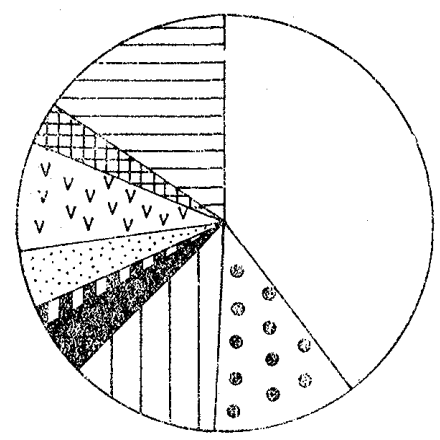

$N=95$
Kitada nol

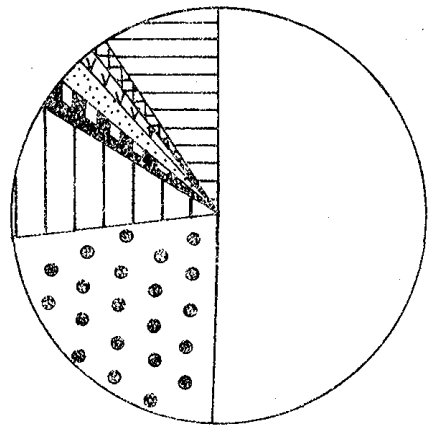

$N=103$
Kitada no. 2

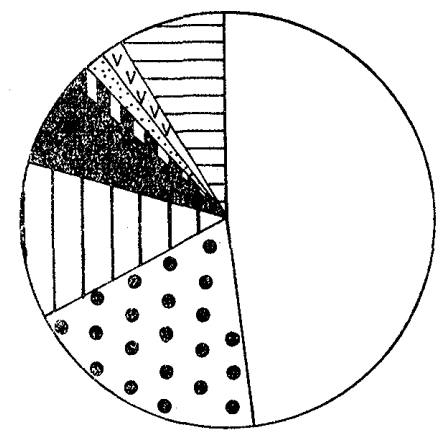

$\mathrm{N}=72$

$L e g \odot n d$

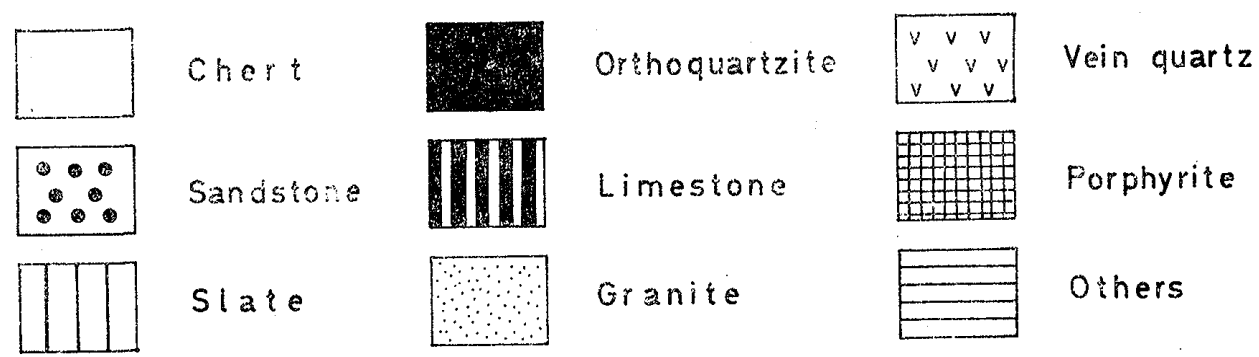

Fig. 4. Composition of the pebbles in the Sarukubo Conglomerate.

orthoquartzite, porphyrite, granitic rocks and hornfels. Pebbles of sedimentary rocks predominate. The sandstone pebbles consist of those various sizes. The pebbles of clayey rocks may be the result of contemporaneous erosion. The pebbles of chert are blue to gray in color and angular in shape; they resemble in all features the chert of the underlying bed. According to Kano (1960) the granitic rocks consist of biotite granite, porphyroidal two mica granite and biotite syenite, and all of them are characterized by their sheared structure. The limestone pebbles are fossiliferous, and KAWADA and KanomatA (1948) reported from them such Permian fossils as Neoschwagerina sp., Pseudofusulina cf. kraffii (SGHel.LWIEN), Schwagerina sp., Triticites sp., and Martina sp. The pebbles of limestone are weathered easily and in the outcrop commonly only their cast are found. Except for the orthoquartzite pebble, the pebbles of the sedimentary rocks resemble the underlying sedimentary rocks. Igneous rocks and orthoquartzite pebbles are exotic. 


\section{Composition of the Sarukubo Con- glomerate}

The composition of the pebbles of the Sarukubo Conglomerate was analysed by the method of counting about 100 pieces larger than $3 \mathrm{~cm}$ in diameter. The composition is shown by the percentage of each species to the total number counted (Hirabayashi, 1969). As shown in Table 2 and Fig. 4, the Sarukubo Conglomerate contains abundant chert pebbles, more than 40 percent. The pebbles of sandstone are next abundant; both hard and soft ones occur in amount of about 15 percent. Slate pebbles amount to about 10 percent of the total. The composition of the Conglomerate at two places, Sarukubo and Kitada, resemble each other but differ in the frequency of the orthoquartzite pebbles as shown in the data of Kitada. The difference in the frequency may be due in part to the comparatively small pebble size. In general the frequency of the orthoquartzite pebbles is about 4 percent.

\section{Description of the Orthoquartzite}

The orthoquartzite pebble is pale chocolate to whitish gray in color. The chocolate color is due to weathering. The size of the orthoquartzite pebble is variable, the largest pebble attains $25 \mathrm{~cm}$ in diameter and the smallest measures about $3 \mathrm{~cm}$ in diameter. The orthoquartzite pebbles are well rounded and thus may be distinguished readily from other kind of pebbles of sedimentary rocks. The orthoquartzite pebbles consist essentially of rounded detrital quartz grains, with small amounts of feldspars and tourmaline grains. The opaque minerals are contained in a traceable amount. The grains are cemented tightly by secondary quartz. Clayey material is also contained in a very small amount in the interstitial pore space. On the quartz grains overgrowth is observed in optical continuity and the original grains are fringed by dust ring P1. 2). The quartz grains consist of monocrystalline quartz without undulate extinction and polycrystalline undulate extinctions are not found.

Feldspars are K-feldspar and plagioclase. K-feldspar shows microperthite structure with albite and plagioclase is albite twinned. The composition of the orthoquartzite is quartz 85$90 \%$, feldspars $0.1-2.7 \%$, tourmaline $1 \%$ to traceable, secondary quartz $8-10 \%$ and matrix $2 \%$ (Table 3). All of the analysed samples are plotted into the orthoquartzite clan (Fig. 5).

The textural parameters of the grain size distribution of the orthoquartzite, calculated according to FoLK's formula (1965), are as follows;

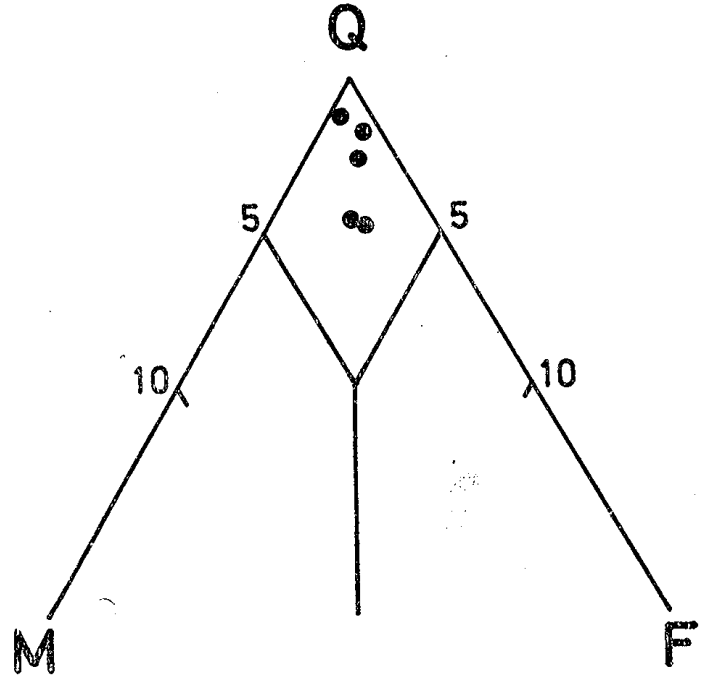

Fig. 5. Composition of the orthoquartzite pebbles of the Sarukubo Conglomerate according to Folk's classification (1965). All of them are plotted in the orthoquartzite clan. $Q$; all types of quartz except streched metaquartzite; plus chert, F; single grains of all type of feldspars; igneous rock fragments both plutonic and extrusive, $\mathrm{M}$; metamorphic rock fragments and mica.

the mean size range -0.19 to $0.55 \phi$, sorting 0.41 to 0.69 , skewness about 0.10 and kurtosis about 0.11 ; so the orthoquartzite is texturally coarse grained, well to moderately well sorted, normal distributed sandstone. The sandstone possessing such textural parameters and composition may be considered to have been deposited through the heavy and or long abrasion process as in an eolian environment (FoLK, 1965). The characters of the orthoquartzite pebble from the Sarukubo Conglomerate well resemble the orthoquartzite pebbles recorded from the Shimanto terrain (The Kishu Shimanto ReseaRCH Group, 1968; TokuokA, 1970), Kamiaso Conglomerate (ADAGHI, 1971) and Tanba belt (Research Group of Tanba Belt, 1971). They are considered to have been derived from Precambrian rocks because of the non-development of the orthoquartzite in the geological systems of the Japanese Islands. The data of the textural parameters and composition are shown in Table 3 and 4.

The roundness of the grains was estimated by the method of CAILLEux. The grains are mostly spheroidal, pollard grains are rare (P1. 2), the value of the roundness is about 0.60 and the highest value obtained is 0.78 (Table 4 ).

5. Roundness and Sphericity of the Pebbles 
Table 3. Mineral composition of the orthoquartzite pebbles and the matrix of the Sarukubo Conglomerate.

\begin{tabular}{r|c|c|c|c|c|c|c|r|c}
\hline & $\mathrm{Q}$ & $\mathrm{F}$ & $\mathrm{M}$ & $\mathrm{T}$ & $\mathrm{H}$ & $\mathrm{RF}$ & $\mathrm{UK}$ & $\mathrm{OV}$ & Matrix \\
\hline $\mathrm{A}-\mathrm{1}$ & 84.1 & 2.7 & $*$ & 1.9 & tr. & $*$ & 0.1 & 8.5 & 2.5 \\
$\mathrm{~A}-2$ & 84.1 & 1.9 & $*$ & tr. & $*$ & $*$ & 0.1 & 12.1 & 1.7 \\
$\mathrm{~B}-2$ & 90.0 & 0.1 & $*$ & tr. & $*$ & $*$ & 0.1 & 8.7 & 1.1 \\
$\mathrm{~B}-3$ & 89.4 & 1.5 & $*$ & tr. & $*$ & 0.04 & 0.1 & 7.8 & 2.4 \\
$\mathrm{C}-1$ & 85.0 & 1.3 & $*$ & 1.1 & $*$ & 0.13 & tr. & 11.0 & 1.3 \\
Matrix & 55.0 & 22.1 & 0.4 & $*$ & 0.2 & 17.6 & 0.4 & $*$ & 4.7 \\
\hline
\end{tabular}

Q; quartz, F; feldspars, $\mathrm{M}$; mica, $\mathrm{T}$; tourmaline, $\mathrm{H}$; heavy minerals, $\mathrm{RF}$; rock fragments, OV; overgrowth, A, B and C; sample number of the orthoquartzite pebble of 72116-7A, B and $\mathrm{G}$, and 1,2 and 3 is the section no. made from each pebble.

Table 4. Grain size distribution and roundress of consisting grains of the orthoquartzite pebbles and the matrix of conglomerate of the Sarukubo Conglomerate; definition of parameters after Folk (1965) and Cailleux (1947). Sample nos. are same to the nos. in Table 3.

\begin{tabular}{c|c|c|c|c|c}
\hline & Mean size & Sorting & Skewness & Kurtosis & Roundness \\
\hline A-1 & 0.51 & 0.43 & 0.30 & 1.17 & $0.63-0.60$ \\
A-2 & -0.19 & 0.71 & 0.11 & 1.23 & $0.78-0.69$ \\
B-2 & 0.30 & 0.62 & 0.05 & 1.47 & $0.57-0.51$ \\
B-3 & 0.23 & 0.63 & 0.22 & 1.12 & $0.54-0.50$ \\
G-1 & 0.28 & 0.69 & 0.02 & 1.23 & $0.55-0.45$ \\
Matrix & 1.60 & 1.17 & 0.25 & 1.53 & $*$ \\
\hline
\end{tabular}

To determine the provenance of the pebbles included in the Sarukubo Conglomerate, analyses were made concerning the difference of the abrasion process, and the roundness and sphericity of every rock species by the method of Dobkins and Fouk (1970). The data obtained from the analyses are listed in Table 5. The hardness and foliation (structure) of the rocks are closely related to the shape of the pebbles and also to their environment (KUENEN, 1956; Drake, 1970; Dobkins and FolK, 1970). The influences of the foliation of the rocks may be represented in the parameter of the sphericity (DRAKE, 1970). The values of the sphericity of the pebbles are mostly above 0.60 , so the pebbles are spheroidal in shape and this suggests that strongly foliated to platy rocks do not exist.

The degree of the roundness ranges from 0.10 to 0.77 . However there exists clear difference in roundness according to the rock species (Table 5). The pebbles in the Sarukubo Conglomerate are classifiable into two groups of low and high roundness (Fig. 6). Chert, slate, hornfels and sandstone pebbles belong to the former category, porphyrite, granite and orthoquartzite pebbles to the latter (P1. 2). These differences are distinct in the outcrops. The roundness of each pebble species is, 0.10 to 0.35 for chert, 0.35 to 0.53 for sand- stone, 0.58 to 0.62 for porphyrite, 0.56 to 0.84 for granite and 0.37 to 0.68 for orthoquartzite. Kuenen (1956) studied experimentally the abrasion process and the relationships between the roundness and distance of the transportation and hardness of the pebbles. He found that long distance transportation makes the value of the roundness increase and the degree of the increase of the roundness value is corresponding to the hardness of each pebble species. From the roundness, chert pebbles are inferred not to have suffered hard abrasion and it is suggested that they may have been supplied from rather short distance and or not through heavy abrasion environment. The granite pebbles are well rounded, and the high value of the roundness may be due to the moderate hardness (KUENEN, 1956), or long distance transportation. From the resemblance of the characters of the pebbles of the sedimentary rocks to the underlying sedimentary rocks, the pebbles except for the orthoquartzite ones, show roundness of low value and thus may have been derived directly from an adjacent area. The chert pebbles also show low value of roundness.

The granite and orthoquartzite pebbles show high roundness. According to KuENEN (1956), granite pebbles can gain a rounded shape (roundness 0.40 to 0.60 ) by moderate distance transporta- 
Table 5. Sphericity and roundness of the pebbles of the Sarukubo Conglomerate; definition of parameter after DoBkins and FoLK (1970).

\begin{tabular}{|c|c|c|c|c|c|c|c|}
\hline & $\mathrm{L}$ & $\mathrm{S}$ & I & $\mathrm{SP}$ & $\mathrm{Di}$ & $\mathrm{Dk}$ & $\mathrm{R}$ \\
\hline Orthoquartzite & $\begin{array}{r}125.0 \\
37.7 \\
39.5 \\
* 113.0 \\
* 55.0 \\
* 90.0 \\
* 34.0 \\
125.0 \\
120.0\end{array}$ & $\begin{array}{l}56.0 \\
24.3 \\
24.5 \\
54.0 \\
36.0 \\
45.0 \\
28.0 \\
80.0 \\
68.0\end{array}$ & $\begin{array}{r}91.2 \\
32.8 \\
32.2 \\
72.0 \\
39.0 \\
80.0 \\
31.0 \\
102.0 \\
92.6\end{array}$ & $\begin{array}{l}0.65 \\
0.78 \\
0.72 \\
0.65 \\
0.54 \\
0.65 \\
0.89 \\
0.79 \\
0.74\end{array}$ & $\begin{array}{l}45.0 \\
16.0 \\
15.0 \\
57.0 \\
19.0 \\
40.0 \\
13.0 \\
51.0 \\
36.0\end{array}$ & $\begin{array}{r}23.0 \\
6.0 \\
6.0 \\
16.0 \\
12.0 \\
27.0 \\
6.0 \\
35.0 \\
24.0\end{array}$ & $\begin{array}{l}0.51 \\
0.37 \\
0.40 \\
0.42 \\
0.63 \\
0.67 \\
0.46 \\
0.68 \\
0.67\end{array}$ \\
\hline Sandstone & $\begin{array}{r}51.1 \\
56.5 \\
38.3 \\
73.5 \\
* 45.0\end{array}$ & $\begin{array}{l}19.0 \\
39.6 \\
27.2 \\
37.9 \\
25.0\end{array}$ & $\begin{array}{l}36.2 \\
47.0 \\
35.0 \\
55.0 \\
30.0\end{array}$ & $\begin{array}{l}0.58 \\
0.83 \\
0.81 \\
0.71 \\
0.77\end{array}$ & $\begin{array}{l}18.0 \\
23.0 \\
17.0 \\
27.0 \\
15.0\end{array}$ & $\begin{array}{r}9.0 \\
6.0 \\
9.0 \\
10.0 \\
6.0\end{array}$ & $\begin{array}{l}0.47 \\
0.26 \\
0.53 \\
0.37 \\
0.40\end{array}$ \\
\hline Chert & $\begin{array}{r}79.3 \\
36.0 \\
52.2 \\
50.0 \\
41.0 \\
36.0 \\
34.8 \\
* 52.0 \\
* 57.0\end{array}$ & $\begin{array}{l}48.8 \\
21.5 \\
30.0 \\
27.3 \\
22.0 \\
22.5 \\
19.3 \\
31.0 \\
45.0\end{array}$ & $\begin{array}{l}74.0 \\
31.2 \\
36.0 \\
48.0 \\
38.0 \\
29.0 \\
31.0 \\
48.0 \\
46.0\end{array}$ & $\begin{array}{l}0.74 \\
0.74 \\
0.78 \\
0.68 \\
0.68 \\
0.84 \\
0.70 \\
0.38 \\
0.77\end{array}$ & $\begin{array}{l}34.0 \\
14.0 \\
18.0 \\
19.0 \\
15.0 \\
13.0 \\
12.0 \\
23.0 \\
17.0\end{array}$ & $\begin{array}{r}12.0 \\
3.0 \\
3.0 \\
2.0 \\
4.0 \\
3.0 \\
4.0 \\
4.0 \\
5.0\end{array}$ & $\begin{array}{l}0.35 \\
0.21 \\
0.16 \\
0.11 \\
0.26 \\
0.22 \\
0.33 \\
0.17 \\
0.29\end{array}$ \\
\hline Granite & $\begin{array}{r}96.2 \\
* 65.0 \\
70.0\end{array}$ & $\begin{array}{l}57.8 \\
20.0 \\
58.0\end{array}$ & $\begin{array}{l}72.2 \\
54.0 \\
64.0\end{array}$ & $\begin{array}{l}0.77 \\
0.48 \\
0.90\end{array}$ & $\begin{array}{l}35.0 \\
27.0 \\
32.0\end{array}$ & $\begin{array}{l}27.0 \\
15.0 \\
27.0\end{array}$ & $\begin{array}{l}0.77 \\
0.56 \\
0.84\end{array}$ \\
\hline Porphyrite & $\begin{array}{r}38.8 \\
* 30.0\end{array}$ & $\begin{array}{l}19.2 \\
23.0\end{array}$ & $\begin{array}{l}32.0 \\
27.0\end{array}$ & $\begin{array}{l}0.66 \\
0.86\end{array}$ & $\begin{array}{l}16.0 \\
12.0\end{array}$ & $\begin{array}{r}10.0 \\
7.0\end{array}$ & $\begin{array}{l}0.62 \\
0.58\end{array}$ \\
\hline
\end{tabular}

* collected from Kitada, size in mm., L, S and I; long, short and intermediate axis, SP; sphericity,

$\mathrm{Di}$; radius of the largest inscribed circle, $\mathrm{Dk}$; radius of the sharpest developed corner, $\mathrm{R}$; roundness

tion of about 30 to $50 \mathrm{Km}$. He stated from the relationship between roundness and weight loss, that the weight loss of the granite pebble is ten times that of the chert pebble. Therefore it may be said that the granite pebble can obtain a rounded form by short distance transportation. Since the orthoquartzite pebble is very hard like that of the chert pebble, and possesses high roundness, the long distance transportation and or hard abrasion is necessary to obtain a rounded shape. This is an important factor for the consideration of the provenance of the orthoquartzite pebbles.

\section{Discussion (Provenance Problem)}

The direction of the Paleocurrent during deposition of the conglomerate is judged to be from SE to NW as determined from the current ripple marks developed in the alternation of the sandstone and shale overlying the Sarukubo Conglomerate (Fig. 3, P1. 1). The paleocurrent direction supports the KANo's suggestion (1960) that the granite pebbles in the Sarukubo Con- glomerate, characterized by the large amount of microcline and sheared structure, are exotic in the Yamizo Mountains and may have been derived from the Hitachi sheared granite, about $35 \mathrm{Km}$ east of Sarukubo (Fig. 1). Kano (1960) also stated that the geologic age of the Sarukubo Conglomerate, from its characteristics and resemblance with known granites in Japan, may be Mesozoic (Jurassic) in age.

The high roundness of the pebbles of the granite and orthoquartzite is the reflection of the abrasion process during transportation. The chert pebbles as hard as orthoquartzite pebbles have angular shape, do not seem to have suffered strong abrasion, resemble the underlying chert bed, and are inferred to have been supplied from the underlying bed. And other pebbles of the sedimentary rocks are similarly considered. The orthoquartzite pebble can not be considered to have originated from some subjacent unit as chert, because of high roundness, which suggests long distance transportation. But the sedimentary 


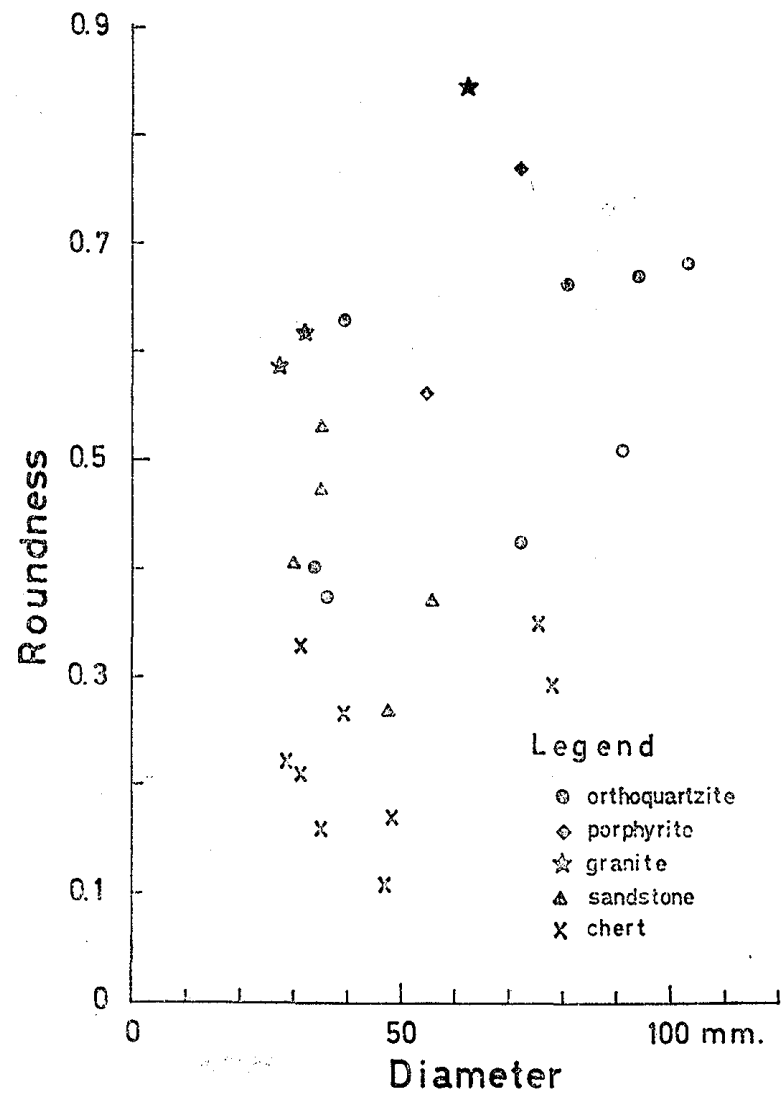

Fig. 6, Relationship between roundness and diameter of the pebbles in the Sarukubo Conglomerate. (diameter is represented by in ermediate axis)

feature of the superjacent strata shows negative evidence for above mentioned consideration.

The probable distribution of Precambrian rocks in the subjacent area of Sarukubo has been suggested by petrologists in the southern Abukuma Plateau from the occurrence of staurolite- and kyanite- bearing metamorphic rocks (KuRODA, 1963; Research Group of the Abukuma PlaTEAU, 1969; WATANABE and Bikerman, 1971). If the orthoquartzite pebble is considered to have been originated from the above, then the basement rock underlying the Paleozoic rocks of the Hitachi area (Devonian) and Toriashi (Garboniferous, Oizumi limestone, Fujrmoto and HATAkeyama, 1938) may be of Precambrian age. But, since the orthoquartzite pebble in the Sarukubo Conglomerate have suffered no metamorphism contrary to the gneissose rocks of Paleozoic age (Abean orogeny, Minato, 1968), it is difficult to consider them to have existed in the Abukuma Plateau during Jurassic time. Considering the origin of the orthoquartzite pebble, it seems to be most reasonable that the ortho- quartzite pebble may have been reworked from underlying conglomerate bed. That is to say, they were probably reworked from the conglomerate of Permian age (Usuginu type) as suggested from the co-existence of fossiliferous limestone pebbles of that age.

Permian fossil bearing limestone pebbles also occur from the basal conglomerate, called Momiya Conglomerate, of the Kume Formation (Lower Pliocene) distributed in the southern part of the Abukuma Plateau (Suzukr and OMORI, 1953).

The Momiya Conglomerate consists of pebbles of sandstone, slate, chert limestone (fossiliferous), crystalline limestone, hornfels, chlorite schist, amphibolite schist, biotite schist, granite, vein quartz and others. The matrix of the Conglomerate is calcareous coarse grained sandstone with abundant molluscan shell fragments. Large pebbles exceed $1 \mathrm{~m}$ in diameter and are of angular to rounded shape. The original rocks of most of the pebbles of the Momiya Conglomerate are represented in the southern part of the Abukuma mountain area, except for the limestone pebbles with Permian fossils. There are no fossiliferous Permian limestones in the hinterland at present. The limestone pebbles, owing to their hardness, were probably not reworked from the older rocks, and are thought to have been derived from a place near the depositional basin.

\section{Summary}

The discovery of orthoquartzite pebbles suggesting a Precambrian origin from the Jurassic Sarukubo Conglomerate is important in interpreting the geological history of the Yamizo Mountains and the southern Abukuma Plateau. From the study of the Sarukubo Conglomerate the following features were recognized;

1). The Sarukubo Conglomerate is the basal conglomerate of the Karasuyama Formation (KANomata, 1961); this is upheld from the distribution and difference in the lithofacies of the subjacent and superjacent strata of the Conglomerate.

2 ). The pebbles of the Sarukubo Conglomerate consist of mostly sedimentary rocks, and, except for the orthoquartzite, are inferred to have been derived from the underlying sedimentary rocks.

3). The granite pebbles are considered to have been derived from the southern Abukuma Plateau (Hitachi district) as suggested from the paleocurrent direction and analysis of the roundness.

4). The orthoquartzite pebbles consist of well rounded detrital quartz grains, and resemble to 
the orthoquartzite pebbles discovered from the Shimanto terrain (The Kishu Shrmanto RESEArch Group, 1968; Tokuoka, 1970), Tanba belt (Research Group of the Tanba Belt, 1971) and Kamiaso Conglomerate (ADAcHI, 1971). All have been considered to have been derived from the Precambrian. The orthoquartzite pebbles of the Sarukubo Conglomerate are not considered to have been derived from the Precambrian directly but to have been reworked from a Permian conglomerate now not represented in the terrain. The possibility of the existence of the Precambrian beneath the southern Abukuma Plateau is reasonable, and perphaps rocks of such age make the basement of the Paleozoic rocks in this area.

5). The Permian limestone pebbles included in the Sarukubo Conglomerate (KawADA and Kanomata, 1948) and Momiya Conglomerate (Suzukr and OMORI, 1953) suggest the former existence of the Permian System in the southern Abukuma Plateau.

\section{References}

ADACHI, M. (1971), Permian intraformational conglomerate at Kamiaso, Gifu Prefecture, Central Japan. Jour, Geol. Soc. Jipan, vol. 77, p. 471-482.

Dobkins, J. E. and Folk, R. L. (1970), Shape development of Tahitinui. Jour. Sed. Petr., vol. 40, p. $1167-1203$.

Drake, L. D. (1970), Rock texture: An important factor for clast shape studies. Jour. Sed. Petr., vol. 40, p. $1356-1361$.

Folk, R. L. (1965), Petrology of Sedimentary rocks. Hemphill's Austin, 159p.

Fujnoto, H. and Hatakeyama, H. (1938), Upper Paleozoic fossils from the Toriashi mountain block, Ibaraki-Ken (preliminally report). Jour. Geol. Soc. Japan, vol. 45, p. 377-378. (in Japanese).

Hirabayashi, T. (1966), Neogene conglomerate and Cenozoic geohistory of the northern Fossa Magna in Central Japan (part 1). Earth Science, vol. 24, p. $79-92$.

KANo, H. (1960), On a granite-bearing conglomerate from the Torinoko massif and its geologic signifcance - Studies on the granite bearing conglomerate in Japan, no. 8. Sci. Rep. Tohoku Univ., 2nd. ser. (Geol.), Special Volume no. 4, p. 476-481 (in Japanese with English abstract).

Kanomata, N. (1961), The geology of the Yamizo, Torinoko and Toriashi mountain blocks and their geologic age. Jour. Fac. Art. and Sci., Chiba Univ., vol. 3, p. $351-367$.

KasaI, K. and KImura, K. (1971), Stratigraphic study on the chert bed of the Yamizo Mountains. Abst. Program, 1971 Annual Meeting Geol. Soc. Japan, p. 466 (In Japanese).

and Oyama, T. (1972), On the Sarukubo Conglomerate of the Torinoko mountain block,
Ibaraki Prefecture. Abst. Program, 1972 Annual Meeting Geol. Soc. Japan, p. 137 (in Japanese).

Kawada, K. (1953), Geological studies on the Yamizo, Torinoko and Toriashi mountain blocks and their neighbourhood in the Northeastern Kwanto district. Sci. Rep. Tokyo Bunrika Daigaku, sec. C, vol. 2, p. $217-307$.

- and Kanomata, N. (1948), On the Paleozoic fossils from pebbles in the conglomerate found in the southern foot of Torinoko mountain, Ibaraki Prefecture. Jour. Geol. Soc. Japan, vol. 54, p. 17-18 (in Japanese).

Kuenen, Ph. H. (1956), Experimental abrasion of pebbles, 2 rolling by current. Jour. Geol., vol. 64 , p. $336-368$.

Kuroda, Y. (1963), Mutual relations between the metamorphic rocks in the Northeast Japan. Earth Science, no. 67, p. 21--29 (in Japanese with English abstract).

Minato, M. (1968), Basementcomplex and Paleozoic orogeny in Japan. Pacific Geology, vol. 1, p. 85-96, Tsukiji Shokan, Tokyo.

Oyama, T., Saito, T. and Takahashi, H. (1972), subsurface geological map of Ibaraki Prefecture, $1: 200,000$ (MS).

Powers, M. C. (1952), A new roundness scale for sedimentary particles. Jour. Sed. Petr., vol. 23, p. $117-119$.

Research Group of the Abukuma Plateau (1969), Polymetamorphism in the Abukuma Plateau with special regards to the discovery of staurolite and kyanitc. Mem. Geol. Soc. Japan, no. 4, p. 83-98 (in Japanese with English abstract).

Shibata, K., Adaghr, M. and Mizutani, S. (1971), Precambrian rocks in Permian conglomerate from Central Japan. Jour. Geol. Soc. Japan, vol. 77, p. $507-514$.

Suzuki, A. and SATo, T. (1972), Discovery of Jurassic Ammonite from Toriashi mountain. Jour. Geol. Soc. Japan, vol. 78, p. 123-215 (in Japanese).

Suzuki, K. and Omori, M. (1953), Etude de la géologie stratigraphique de la systéme Tertiare dans le district de Ota-machi, Ibaraki Pref. (Etude de la géologie historique de la systéme Néozoique au Bord de S-W du Plateau Abukuma part II). Jour. Geol. Soc. Japan, vol. 59, p. 35-46 (in Japanese with French abstract).

The Kishu Shimanto Research Group (1968), The study of the Shimanto terrain in the Kii Peninsula, Southwest Japan (part 2) - The present status of the research and southern Formerland in the Pacific Ocean -. Earth Science, vol. 22, p. 224-231 (in Japanese with English abstract).

Tokuoka, T. (1967), The Shimanto terrain in the Kii Peninsula, Southwest Japan, - With reference to its geologic development viewed from coarser clastic sediments. Mem. Fac. Sci., Kyoto Univ., ser. Geol. and Mineral., vol. 34, p. 35-74.

(1970), Orthoquartzite gravels in the Paleogene Muro Group, Southwest Japan. ibid., vol. 37, p. 113-132.

Watanabe, J. and Bikerman, M. (1971), K-Ar age 
of the Nishidohira gneiss complex in the Abukuma mountains, Japan. Earth Science, vol. 25, p. 23-26 (in Japanese with English abstract).

$\begin{array}{cccccc}\text { 猿 } & \text { 久 } & \text { 保 } & \text { 礫 岩 } \\ & \text { 大 } & \text { 上 } & \text { 和 良 } & \\ & & & & \\ & & \text { (要 } & \text { 旨) } & & \end{array}$

近年，先カンブリア系起源と推定されるオルソコーツ アイト碩の産出が各地から垠告され，日本列島の基盤に 関する新らたな知見を与えている。しかしながら，この オルソコーッアイト磂つ産出はフネッサ・マグナ以西の 西南日本に限られていた。

筆者は今回, 八溝山系に分布するシュラ系の基底磪岩,

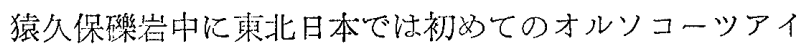
卜礫が多量に含有されていること発見した。このオル ソコーツアイト䂺は円磨度が非常に高く，鏡下観察の結 果西南日本で報告されたものに酷似している。ささらに， 同磼岩に対して詳細な堆積岩石学的检討完加えた結果, このオルソコーツアイト䃯は再食礫であると結諭され， 供給源は砅岩層の上位の地層中に発達する漣痕および共

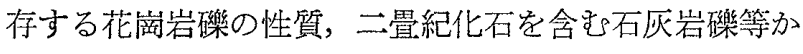
ら南部阿武德高原に発達していた二畳系礫岩と推定され る. 現在，同高原南部には二畳系の分布が知られていな いが，同高原南端に発達する鮮新統茂宮碩岩は二畳紀化

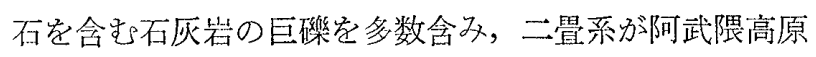
南部に発達していたことを裹づけている.

さらに，このオルソコーツアイト爍の発見は南部阿武

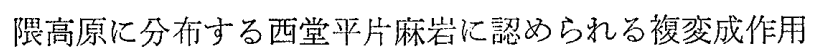
の存在事実とあわせ，同地に先カンブリア系の存在を， さらに同系が阿武隈および八洴山系の基盤を形成するこ とを示唆する根拠を与をた。

\begin{tabular}{|c|c|}
\hline 地 & 名 \\
\hline Karasuyama ………烏山 & Ogawa \\
\hline Kasama …………...笠間 & Sarukubo ……..猿久保 \\
\hline Keisokusan (Toriashisan) & Toriashisan (Keisokusan) \\
\hline ……鷄足山 & 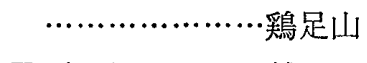 \\
\hline Kitada ……….....北田 & Torinokosan \\
\hline Kunimiyama……国見山 & Yamizo …………八溝 \\
\hline Momiya ……………茂宮 & Yoshida ……………吉 \\
\hline ……...那珂 & \\
\hline
\end{tabular}


Explanation of Plates

\section{Plate I}

1 View of the uppermost horizon of the Sarukubo Gonglomerate. An outcrop along the road leading from Sarukubo to Yoshida, Ogawa Village, Ibaraki Prefecture.

2. Cobble size conglomerate of the Sarukubo Conglomerate.

3 Pebble size conglomerate of the Sarukubo Conglomerate; middle horizon.

4 Ripple marks developed in the sandstone of the alternation of sandstone and shale in a cliff along the road from Sarukubo to Yoshida.

\section{Plate II}

1. Photomicrograph of an orthoquartzite pebble (A-2) from the Sarukubo Conglomerate. Note the well-rounded detrital quartz grains cemented by secondary quartz. Crossed nicols.

2 Photomicrograph of an orthoquartzite pebble (A-1) from the Sarukubo Conglomerate. Note the well rounded detrital quartz grains cemented by secondary quartz as optically continued and containing a very small amount of clay minerals. Crossed nicols.

3 Pebbles of the Sarukubo Conglomerate showing different shapes according to rock species; 1 , granite, 2, orthoquartzite, 3,4 and 5 , chert pebbles. 






